\title{
Policy and Administration
}

\author{
Lawrence Clark Powell
}

$\mathrm{T}$ EN YEARS ago, when I was a brash junior on the staft of a western university library, I wrote two papers on the problems and uses of rare books in college and university libraries. It can be revealed now that these papers were the product of my own enthusiasm and other librarians' experience. I fearlessly sent questionnaires to such experts as Randolph Adams, William Jackson and Christopher Morley. All of this was done in the optimism of youth and served no immediate purpose other than to relieve my own spleen. For I was employed in a library which had no rare book room nor any plan to establish one. During this idealistic outburst I accumulated much information on what not to do, then filed my findings, and went back to "washing dishes" in the Order department.

Five years ago my idealism found outlet. One of the questions asked of candidates for the librarianship in a western university by the faculty committee appointed by the President of the University, was "If you become Librarian, what will you do about rare books and special collections?" Since then I have been endeavoring to put into action some of the answers which I made.

This paper will be a partial report on my experience in establishing the policy and administration of a department of special collections in a university library, as well as in directing an already founded and separate rare book library belonging to the same university. No questionnaires were devised. No review is offered of the extensive literature on the subject, most of which I have read at one time or another, and which is readily available. This paper is not for Randolph Adams and William Jackson, those good friends of mine in Ann Arbor and Cambridge, both of whom have admirably solved their rare book problems; but was written rather for university librarians who have not yet devised entirely effective policies and administrative practices governing the acquiring and servicing of rare books. Rather than universal answers and fixed rules, I shall offer some observations based upon personal experience on one campus, hoping that there will be some typical data of value.

My topic is the policy and administration of rare book collections in university libraries. This can be more simply stated as What to Get, How to Get It, and finally, How to Organize It for Use.

A policy for the collecting of rare materials should be determined by the teaching and research needs of the faculty and students, and by regional resources and cooperative plans in a given area.

We can dispose of teaching needs by the flat statement that rare books have small place in the undergraduate program. The very nature of rare books and manuscripts - their scarcity and their value-means that they cannot be subjected to steady and heavy use. The skillful employment of exhibits is probably the best way to acquaint the university undergraduate with the treasures of the rare book room. This problem of heavy use does not exist, of course, in the col- 
lege where a rare book library, such as the Chapin at Williams, can be effectively and safely used to document teaching.

In a university research program, particularly in the humanities with their vast printed sources, the emphasis on collecting rare materials will be determined by the faculty's needs rather than determine the needs themselves. Every university library should formulate a code of acquisitions which will clearly state the collecting objectives of that library. This code should be the joint product of the library staff and the faculty library committee.

In the field of rare books the best policy is to build on strength, rather than to attempt to collect rare books in every area of university research. This practice of building on strength can be admirably observed at Michigan in the Clements Library, at Texas in the Wrenn, at California in the Bancroft, and at U.C.L.A. in the Clark. Indiana is likewise enriching its Defoe and Folklore collections, Illinois its Milton, and Washington the Pacific Northwest materials, in which they all boast unusual strength.

In larger universities, with their multitude of department and graduate school collections not always under a single administration, particular care should be taken to avoid the needless duplication of costly materials. This situation has been met at Northwestern through coordination by a Library Council. California with its eight separate campuses is likewise pooling its library resources through a statewide library council.

Regional as well as campus cooperation is essential if rare book collections are to attain maximum usefulness to scholars. In Southern California such cooperation is practiced between the Huntington and the Clark libraries. Because of the Huntington's immense strength in STC books the Clark seldom buys a rare book before 1640 , and gives careful consideration to the purchase of any later book if it is already in the San Marino collection.

I want to pay tribute here to the work of Donald Wing in compiling his catalog of English books I640-1700. At the Clark Library we order no books in this period without first determining their American location.

From emphasis on regional cooperation I shall proceed to an even larger concept and call for a national program of cooperation between rare book libraries. I suggest that we form a Council of libraries and collections which concern themselves exclusively with rare books. This would be composed of the Directors of such separate libraries as the Clements, the Houghton, the Morgan, the Folger, the Chapin, the Newberry, the Huntington, the Bancroft, and the Clark, as well as the curators and keepers of rare book collections at Yale, Princeton, Columbia, Stanford, Texas, and elsewhere. Matters of acquisitions, processing, servicing and maintenance could be profitably discussed at regular meetings, instead of waiting every ten years for a place on the ACRL agenda.

I come now to my second major point: How to Get Rare Books. There are two principal ways to do this, by purchase and by gift-and of the two, the latter is by far the most satisfying to the heart (and purse) of the librarian. Most of the great rare book libraries and collections in this country now in public hands 
came thereto from philanthropic donors. The names of Brown, Clements, Folger, Huntington, Wrenn, Morgan, Chapin, Clark, Cushing, and others should be on the lips of every tender library school graduate. Although these men are dead, and their breed may well be tax-extinct, their collections live on as some of the greatest monuments to nineteenth century American Capitalism.

In succession to these benefactors we now have the mopping-up groups, known as the Friends of the Library. Two of the most successful of this kind of organization are those at Princeton and at the Huntington. University libraries interested in forming such groups should proceed with caution. Overhead expenses of printing, postage, and entertainment can more than match the value of gifts received, with the result that goodwill is the only entry to appear on the profit side of the ledger. If alumni and friends will underwrite all promotional expenses, there is still the cost of spark-plugging the group. In order to insure integrated planning with the rest of the university library program, this secretary should be a member of the library staff, preferably in the rare book division. A portion of his salary might thus be charged to the overhead of the friends group and supplied from sources outside the library's budget.

Whether or not a university library has such a friends group, it should not overlook the value to a rare book program of some sort of publication which will inform potential donors of what the library has and has not. An outstanding example of a publication sponsored by the library itself is the Texas Library Chronicle. At U.C.L.A. the head of the Acquisitions Department edits a mimeographed bulletin called Acquisitive Notes, which is aimed at telling the faculty what we have and telling friends what we haven't. Fifteen hundred copies are issued two or three times a year, at a mimeographing and mailing cost of about $\$ 30$ per issue. Results have been extraordinary.

We plan also at U.C.L.A. to use nicely printed leaflets to announce the acquisition of choice collections. The Olive Percival Collection of Children's Books was described in a two-color leaflet which also pointed out desiderata, with the result that nearly a dozen donations were received from collectors throughout the country. The University of California Library Council is currently planning a quarterly journal of acquisitions which will serve the interests of the statewide university libraries.

Rare book libraries and special collections perform a useful service to scholars and librarians by publishing reports of their acquisitions. Lawrence Wroth's accounts of the Carter Brown's annual growth are justly famous. William Jackson's acquisitions reports on the Houghton Library are the joy and despair of bookmen everywhere, so rich are they in so many periods and subjects. Rare book receipts are regularly reported in the library bulletins of Yale, Princeton, Texas, and Indiana, to name a few. The Morgan and the Clark libraries report at five and ten year intervals respectively on the growth of their collections.

Memorial funds honoring local collectors, professors, and bibliophiles can also be sponsored by university libraries to the mutual benefit of the family and the library. Such a memorial was founded last year by my library in memory of 
Ernest Dawson, a local bookseller who was known throughout the world.

Smaller endowments should not be ignored. As James Babb has observed, Yale is still buying books on income from its first gift fund of $£$ Io in 1763 .

The purchase of rare books will obviously depend on the total funds available in a given library. Younger and smaller institutions and those depending upon state appropriations for their funds will need most of their money for "run of the mill" and "bread and butter" purchasing, whereas older and wealthier libraries will benefit from endowments intended wholly for the purchase of rare books on specific subjects. Acquisitions on microfilm and photostat make possible the quick enrichment of impecunious libraries, without the problems of protecting fragile and unique originals. For less than a thousand dollars any library can possess on photostat the entire Shakespeare holdings of the Huntington Library. Copies are not just as good as originals, no matter what the cynical professor says to the contrary. William Jackson's paper on "Some Limitations of Microphotography" should be at the side of all rare book librarians and handed out to those persons who profess contempt for originals.

I come now to the third and final section of my paper. We have considered what a library should get and how to get it. What then should be done with the rare book collection in the way of location and staff? A university's rare book library has the dual responsibility of serving and conserving. It must serve research, and at the same time it must conserve its irreplaceable riches. Familiar to all is the classic paper on this problem; I refer to Randolph Adams' "Librarians as Enemies of Books."

When a university library is bequeathed a rare book collection with a separate building to house it, located at a distance from the main library, numerous problems arise, such as have been encountered at U.C.L.A. in the administration of the Clark Library. The ideal situation is probably at Harvard where the Houghton Library is connected umbilically to the Widener. Most university libraries however find it necessary to house the rare book collection in the main library building. What is the ideal arrangement in this event?

Quarters should be large enough to provide space for the processing of mate- rials, their housing, and their controlled use by the scholar. At U.C.L.A., where we had the opportunity to locate the rare book room in the best spot in the existing building, we put it at the rear of the wing on the second floor, in tandem with the Acquisitions department and the Librarian's office, and a short distance from the public catalog and loan desk. All of the Main Library's rare books, manuscripts, and archives will at first be housed within the suite of rare book rooms, but allowance is made for future expansion into a section of the adjoining main book stack. Air conditioning is essential. Our problem in the Southwest is of excessive dryness and dust rather than of cold and damp. Good lighting is absolutely essential. Restricted entrance and exit and a central service desk are necessary for protection against theft and careless use. The rare book room should provide each reader with a printed copy of its rules. Use of the collections should be regarded as a privilege; careless readers should be educated, 
malicious ones ejected. Sound-proof typing cubicles should be present. Photocopying services should be nearby. At U.C.L.A. the photographic laboratory, which will be supervised by the head of the rare books department, is in the basement immediately below the rare book room.

So much for location. What about staff? The rare book room should be a separate department of the library, or in a younger place at least a division of the department of Special Collections which might also include maps, music, archives, manuscripts, and other non-book materials.

Who is to head these specialized activities?

If the library wishes to emphasize acquisition of rare materials rather than the service they will be put to, then it is not necessary that a library school graduate be employed. My belief is that the most effective rare book collection will endeavor to strike a nice balance between the getting and the using. If the collection is to be an integrated part of the library's service organization, then its head should be a person with some understanding of the aims of the other departments in the library. He should be trained in the history and techniques and ideals of librarianship, he should also have pursued graduate work to an M.A. or Ph.D. degree, he should have worked in other departments and other libraries, he should have an equal feeling for books and for people, and lastly he should have an abiding contempt for the rule of thumb.

The size of the staff will depend of course on the size of the collection and the numbers to be served. I recommend the part time employment of undergraduate and graduate students who have evidenced a respect and a love for rare materials. They make better attendants and clerks than business school graduates, and they can sometimes be recruited for librarianship to the improvement of the profession.

Suffice it to say here, that members of rare book staffs should be chosen because of their feeling for the materials, their training in librarianship, and their knowledge of subject fields with which they may be concerned. Personnel should be encouraged in bibliographical and subject investigations of their own making, that they may have a working knowledge of research materials and processes, and maintain an alert attitude toward books and people. However, they must not in time become research fellows but librarians, realizing that their primary professional interest lies in conservation and public service and in the library policies and processes contributing to these ends. Our library schools are notoriously deficient in the training offered for potential workers in rare book rooms and special collections.

To conclude, I think I am safe in saying that the cultural maturity of a library can be pretty well gauged by the policy it has and the administration it provides for rare books. Maturity does not automatically go with age. To be old is not necessarily to be wise. A library seeking to inaugurate or to improve a method for handling rare books will do well to look widely around the country, and then to put these observations together into an approximation of the ideal: Rare books deserve no less. 